First Comes Legalization, Then

Comes What? Tips for Washington and Colorado to Help Break the Cycle of Selective Prosecution and Disproportionate Sentencing

Introduction

I. The Status Quo

II. Ushering in a New World Order? Colorado and Washington.

A. Discretion, Criminal Records, and Licenses ................ 1260

B. Harsh Penalties for Refusing Breath Tests................... 1261

C. Juvenile Conversion of Misdemeanors to Felonies...... 1262

III. Cautionary Principles for Other States Considering

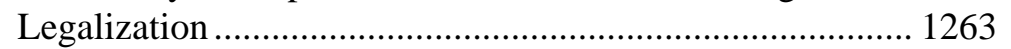

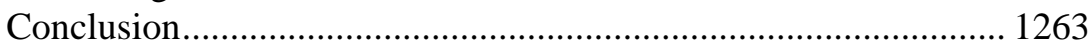

\title{
INTRODUCTION
}

$\mathrm{O}$ vert permeation of racial bias has existed in our legal system for centuries. While we have made some progress, the vestiges of racial stereotypes still remain. One particularly shocking-and recent-example was the prosecutor's statement in the United States Supreme Court Case Calhoun v. United States. In that case, the defendant, Calhoun, an African American, was arrested while in a car with two others who were attempting to buy drugs from an

* Associate Professor of Law, University of Mississippi School of Law; B.A. 1996, Colgate University; J.D. 2000, Harvard Law School. I thank the University of Mississippi School of Law for its support. 
undercover officer. ${ }^{1}$ During his trial for conspiracy, the prosecutor questioned Calhoun about his claim that he was unaware of his friends' activities, stating 'You've got African-Americans, you've got Hispanics, you've got a bag full of money. Does that tell you-a light bulb doesn't go off in your head and say, This is a drug deal?”, In response, the Court aptly noted that " $[\mathrm{b}] \mathrm{y}$ suggesting that race should play a role in establishing a defendant's criminal intent, the prosecutor . . . tapped a deep and sorry vein of racial prejudice that has run through the history of criminal justice in our Nation."3 Policymakers must always be conscious of that vein of prejudiceeven in enacting progressive reforms. I consider here how those implementing the marijuana initiatives in Washington and Colorado might do so.

While racial profiling is a documented problem with law enforcement in general, ${ }^{4}$ the record is even more replete with examples of race-based profiling in the implementation of drug laws. ${ }^{5}$ This practice has led to selective arrests and prosecution for petty drug crimes, in turn resulting in the systematic incarceration of people of color. ${ }^{6}$

Scholars and citizens alike have registered their outcry against current drug policies. Some scholars, for example, assert that courts only care about providing symbolic equality to traditionally subordinated groups without addressing the substantive inequities they experience in the legal system. ${ }^{7}$ Others, notably Michelle Alexander, label the mass incarceration and veritable caste system resulting from biased enforcement of drug laws the "New Jim Crow."8

Regardless of the label, this pattern of subjugation is real, and may even worsen, if burgeoning reform efforts are not designed to ameliorate it. The recent modifications of drug laws in Colorado and

\footnotetext{
1 Calhoun v. United States, 133 S. Ct. 1136 (2013).

2 Id. at 1136.

3 Id. at 1137.

4 Steven R. Morrison, Note, Will to Power, Will to Reality, and Racial Profiling: How the White Male Dominant Power Structure Creates Itself as Law Abiding Citizen Through the Creation of Black as Criminal, 2 Nw. J. L. \& SoC. POL'Y 63, 77-80 (2007).

5 See generally Traci Schlesinger, The Cumulative Effects of Racial Disparity in Criminal Processing, 2007 J. INST. JUST. \& INT’L STUD. 261 (2007).

6 Id.; see infra Part II.

7 See, e.g., Paul Butler, One Hundred Years of Race and Crime, 100 J. CRIM. L. \& CRIMINOLOGY 1043, 1045 (2010).

8 E.g., Michelle Alexander, The New Jim Crow, 9 OHIO ST. J. CRIM. L. 7,7 (2011).
} 
Washington encapsulate this danger. Portions of the Washington statute, ${ }^{9}$ in particular, threaten to maintain the status quo and to perpetuate stereotypes of African Americans and Latinos. The states' approaches to marijuana legalization signal that it is time now, more than ever, to reevaluate and restructure our current drug laws to prevent selective prosecution as well as the disproportionate incarceration of men and women of color. In reforming current laws, however, states must avoid incorporating terms and limitations that might trigger new forms of profiling.

Part I of this Article proceeds by exposing the disproportionate impact of drug policies on men and women of color. Part II then discusses the recent laws in Washington and Colorado and their potential for perpetuating the prevailing practice of selective enforcement. Finally, Part III espouses cautionary principles for other states considering legalization.

\section{THE STATUS QUO}

Laws motivated by moral dirigisme ${ }^{10}$ are not new. Such laws are enacted in great part in order to guide moral behaviors. Rules outlawing murder and theft, to a certain extent, are, along with drug laws, examples of such motivation. ${ }^{11}$ Drug laws, however, are particularly problematic because of their ineffectiveness, selective implementation, and the harm they cause to disadvantaged groups. ${ }^{12}$ The numbers tell the story. African Americans account for approximately forty-three percent of persons convicted of drug felonies in state courts, compared to fifty-five percent for whites; for those admitted to state prisons with new convictions for drug offenses, the numbers are even more grim: African Americans account for more than half, while whites are only one-third. ${ }^{13}$ That is true despite the fact that numerous studies show that African

\footnotetext{
9 See WASH. REv. CodE ANN. §§ 69.50.101-.606 (West, Westlaw through 2013 legislation).

10 In an earlier article, I argue that drug prohibition causes more harm than good and that the high costs of prohibition are not justified. See generally Michèle Alexandre, Sex, Drugs, Rock \& Roll and Moral Dirigisme: Toward a Reformation of Drug and Prostitution Regulations, 78 U. MO. KAN. CITY L. REV. 101 (2009).

11 Id.

12 Drug War Statistics, DRUG POL'Y AlLiANCE, http://www.drugpolicy.org/drug-war -statistics (last visited Apr. 8, 2013).

13 Jamie Fellner, Race, Drugs, and Law Enforcement in the United States, 20 STAN. L. \& POL'Y REV. 257, 274 (2009).
} 
Americans do not use or sell drugs at higher or appreciably higher rates than whites; ${ }^{14}$ some show, in fact, that they do so at lower rates. 15

Nowhere is this fact more evident than in the enforcement of laws regulating marijuana. ${ }^{16}$ These laws have had systematic and disproportionate effects on men and women of color in America with little change and intervention from the government. ${ }^{17}$ The privatization of prisons ${ }^{18}$ and monthly quotas for arrests ${ }^{19}$ have imposed added financial incentives and pressures on law enforcement. Furthermore, there is some support for the argument that these laws have helped create the same pattern of subjugation across the world. ${ }^{20}$

The global regulatory framework created by the United States often puts local communities at risk despite obtaining very poor results from such regulations. ${ }^{21}$ Around the world, women and children are treated with automatic suspicion due to their provenance ${ }^{22}$ while drug trafficking networks move closer to communities in order to evade

14 Alexander, supra note 8, at 13 n.25 (citing, for example, HOWARD N. SNYDER \& MELisSA SiCKMUND, U.S. DEP'T OF JUSTICE, NAT'L CTR. FOR JUVENILE JusTiCE, JUVENILE OFFENDERS AND VICTIMS: 2006 NATIONAL REPORT 81 (2006), available at http://www.ojjdp.gov/ojstatbb/nr2006/downloads/NR2006.pdf; EELUM ARYA \& IAN AugARTEN, CAMPAign FOR YOUTH JUSTICE, CRITICAL CONDITION: AFRICANAMERICAN YOUTH IN THE JUSTICE SYSTEM 15 tbl. 5, 19 (2008), available at http://www.campaignforyouthjustice.org/documents/African AmericanBrief.pdf).

15 Meghana Kakade et al., Adolescent Substance Use and Other Illegal Behaviors and Racial Disparities in Criminal Justice System Involvement: Findings from a US National Survey, 102 AM. J. PuB. HEALTH 1307, 1307 (2012) (noting that a longitudinal survey of nationally-represented youths showed that "African American youths were more likely than Whites to have been arrested multiple times .... White youths, however, had higher rates of substance use than did African American youths).

16 Id.

17 See Alexander, supra note 8, at 9; Geneva Brown, The Wind Cries Mary-The Intersectionality of Race, Gender, and Reentry: Challenges for African-American Women, 24 J. CIV. RTS. \& ECON. DEV. 625, 629-32 (2010).

18 Llewellyn Hinkes-Jones, Privatized Prisons: A Human Marketplace, L.A. REV. BooKs (Jan. 10, 2013), http://lareviewofbooks.org/article.php?id=1302\&fulltext=1.

19 See Margot Adler, At "Stop-And-Frisk" Trial, Cops Describe Quota-Driven NYPD, NPR (Mar. 21, 2013, 5:01 PM), http://www.npr.org/2013/03/21/174941454/at-stop-and -frisk-trial-cops-describe-quota-driven-nypd.

20 See generally Maureen Norton-Hawk, Exporting Gender Injustice: The Impact of the U.S. War on Drugs on Ecuadorian Women, 18 CRITICAL CRIMINOLOGY 133 (2010) (arguing that the increase in the number of women incarcerated for drug offenses in Ecuadorian prisons is related to the U.S. war on drugs).

21 See generally Alexander, supra note 8; Butler, supra note 7; Fellner, supra note 13.

22 See e.g., Solimar Santos, Comment, Unintended Consequences of United States' Foreign Drug Policy in Bolivia, 33 U. MIAMI INTER-AM. L. REV. 127 (2002). 
detection. ${ }^{23}$ For example, people of color are scrutinized and routinely profiled when traveling due to fears that individuals traveling in and out of the United States might be serving as mules for drug lords. This stereotype persists despite evidence showing that drug smugglers are predominantly U.S. citizens and are often white. ${ }^{24}$ As the Center for Investigative Reporting (CIR) documented, "U.S. citizens comprise the overwhelming amount of drug-related arrests in recent years by the Border Patrol. They're about 80 percent of the total." 25 The stereotypes prevalent in enforcement of domestic laws are, thus, duplicated in the immigration context.

Furthermore, global restrictions imposed by drug laws have left communities vulnerable as drug traffickers move closer to residential areas in order to avoid detection. For instance, in 2012 the urban center of Medellin, Colombia-having finally distanced itself from the specter of Pablo Escobar's cocaine empire-was overrun by the violent Caribbean criminal group, the Urabeños. ${ }^{26}$ Similarly, in urban America, drug gangs often run their operations in housing buildings and apartments, exposing children to great danger.

Efforts to dismantle drug networks are ineffective because they are either based on stereotypes as to who fits a drug dealer's profile, ${ }^{27}$ or only punish low-level criminals who deal in small amounts of drugs. ${ }^{28}$ For example, a study on the enforcement of marijuana laws in New York City found:

Most of the people arrested possessed only a small amount, usually a few grams in a marijuana "joint" or "blunt," or in a small, plastic bag—a "nickel bag” (\$5) or a “dime bag” (\$10).

23 Mexican Drug Cartels Move Deeper into US to Tighten Grip on Narcotics Market, GUARDIAN (Apr. 1, 2013, 12:45 EDT), http://www.guardian.co.uk/world/2013/apr/01 /mexican-drug-cartels-deeper-us; Elyssa Pachico, Sinaloa Cartel Expands Reach in Peru, Australia, INSIGHT CRIME (Jan. 3, 2011), http://www.insightcrime.org/news-analysis /sinaloa-cartel-expands-reach-in-peru-australia.

24 Robert Beckhusen, Drug Cartel Mules Are American as Apple Pie, Border Patrol Data Shows, WIRED (Mar. 27, 2013, 3:39 PM), http://www.wired.com/dangerroom/2013 /03/citizen-smugglers/.

25 Id.

26 Elyssa Pachico, Urban Battle in Medellin as Outsider Drug Cartel Moves In, INSIGHT CRIME (June 28, 2012), http://www.insightcrime.com/investigations/urban-battle -in-medellin-as-outsider-drug-cartel-moves-in.

27 Michael Tonry, The Social, Psychological, and Political Causes of Racial Disparities in the American Criminal Justice System, 39 CRIME \& JUST. 273, 277 (2010).

2810 Facts About Marijuana, DRUG POL'y AlLIANCE, http://www.drugpolicy.org /drug-facts/10-facts-about-marijuana (last visited Apr. 8, 2013) ("More than 800,000 people are arrested for marijuana each year, the vast majority of them for simple possession.”). 
This huge number of arrests has not been distributed equally among the people of New York City. Most people arrested were younger than 26 years and 91\% were males arrested primarily in less affluent neighborhoods in all five boroughs.

New York's marijuana arrests have long been racially skewed, but because of the eleven-fold increase in arrests beginning in 1997, a great many more young Blacks and Latinos have been arrested than ever before in the city's history.

Many economists have denounced this status quo not only as ineffective and a waste of local and federal resources, but also as biased. $^{30}$ Further, the systematic imprisonment of African Americans and Latinos raises questions about criminal law's ineptitude when it comes to the equitable enforcement of its laws. In the post civil rights legal construct, it has become obvious that one of the major problems with drug laws lies in the assumption of neutrality and color blindness. These deeply rooted assumptions make it even harder to successfully question the discretion afforded to law enforcement officials.

Such discretion increases the likelihood of racially inequitable administration of the law. ${ }^{31}$ This idea is supported by the statistical dichotomy between prosecuted, non-white, urban drug users as compared to prosecuted, suburban, white drug users. ${ }^{32}$

\section{II}

\section{USHERING IN A NEW WORLD ORDER? COLORADO AND WASHINGTON}

In a statute passed on January 1, 2013, Washington created a regulatory scheme whereby a state commission monitors the

29 Harry G. LeVIne \& Deborah Peterson SMall, N.Y.C. Civil Liberties Union, MariJuana ArRest Crusade: Racial Bias and Police Policy in NeW York City, 1997-2007, at 8 (2008), available at http://www.nyclu.org/files/MARIJUANA-ARREST -CRUSADE_Final.pdf.

30 See generally Chris Doyle \& Jennifer C. Smith, Crime and Drugs: An Economic Approach (Univ. of Warwick Dep't of Econ., Working Paper No. 477, 1997), available at http://www2.warwick.ac.uk/fac/soc/economics/research/workingpapers/publications/crim drug.pdf.

31 See, e.g., United States v. Vasquez, No. 09-CR-259 (JG), slip op. at 4 (E.D.N.Y. Mar. 30, 2010) (criticizing federal prosecutors' decision to charge a street-level dealer with conspiracy, which carries a mandatory five-year minimum prison sentence).

32 See generally Margaret E. Finzen, Note, Systems of Oppression: The Collateral Consequences of Incarceration and Their Effects in Black Communities, 12 GEO. J. ON POVERTY L. \& POL'Y 299 (2005); Gary Ford, The New Jim Crow: Male and Female, South and North, From Cradle to Grave, Perception and Reality: Racial Disparity and Bias in America's Criminal Justice System, 11 RutGERs RACE \& L. REV. 324 (2010). 
production and limited distribution of marijuana. ${ }^{33}$ The stated purpose of the new law is primarily to raise money and to establish financial structures for funds collected through the sale of the product. ${ }^{34}$ It is notable that the law's goal is also to "stop treating adult marijuana use as a crime and try a new approach.",35

However, history and experience have revealed that good intentions are not always sufficient. In fact, as critical race theory scholars have formulated, unequal structures are so ingrained in our institutions that there is always a risk of duplicating past injustices, even when the old problematic frameworks are discarded. ${ }^{36}$

Trying to dismantle the old approach to marijuana, the Washington statute allows possession of a small amount of the drug by persons twenty-one and older. ${ }^{37}$ The act also responds to concerns with due process, right to privacy and overcriminalization. ${ }^{38}$ Accordingly, the law creates a scheme for the distribution of funds raised through the sale of marijuana. ${ }^{39}$ The act also alleviates abuse concerns by criminalizing both driving under the influence and distribution of the drug to minors. ${ }^{40}$

Still, even under the framework established by the Washington statute, some of the same subjugating patterns ofcurrent drug laws risk being repeated, if not carefully avoided. More specifically, the Washington statute contains three problematic features: (1) consideration of criminal records when assessing an application for a processing or retail license, (2) disproportionate consequences resulting from refusal to take a breath test when stopped for suspicion of driving under the influence, and (3) juvenile conversion of misdemeanors to felonies.

\footnotetext{
33 WASH. REv. CODE ANN. §§ 69.50.101-.609 (West, Westlaw through 2013 legislation).

342013 Wash. Legis. Serv. ch. 3, § 1(2), at 1 (West); see also § 69.50.530.

$35 \mathrm{Id}$. § 1 at 1.

36 See generally Reginald Leamon Robinson, Human Agency, Negated Subjectivity, and White Structural Oppression: An Analysis of Critical Race Practice/Praxis, 53 AM. U. L. REV. 1361 (2004).

37 WASH. REV. CODE ANN. § 69.50.331(1)(a).

38 Id. §§ 69.50.304(d), .312(d)-(e), .334, .360-.366.

39 Id. §§ 69.50.530, .540.

40 Id. §§ 46.61.502(b)-(d), 69.50.406.
} 


\section{A. Discretion, Criminal Records, and Licenses}

Washington makes the grant of a license to process or operate a marijuana retail outlet contingent on a criminal background check. ${ }^{41}$ In reviewing applications for licenses or in considering denial, suspension, or renewal of licenses, the state liquor control board overseeing the operation of legal marijuana in the state may consider any prior criminal record. ${ }^{42}$ Furthermore,

[t]he state liquor control board may submit the criminal history record information check to the Washington state patrol and to the identification division of the federal bureau of investigation in order that these agencies may search their records for prior arrests and convictions of the individual or individuals who filled out the forms. The state liquor control board shall require fingerprinting of any applicant whose criminal history record information check is submitted to the federal bureau of investigation. ... Subject to the provisions ofthis section, the state liquor control board may, in its discretion, grant or deny the renewal or license applied for. Denial may be based on, without limitation, the existence of chronic illegal activity documented.

It should be noted that, under the statute, the licensing board is required to give "substantial weight" to an incorporated "city, town, or county legislative authority" objecting to the grant of a license based upon "chronic criminal activity[;]"44 which is defined as:

(a) a pervasive pattern of activity that threatens the public health, safety, and welfare of the city, town, or county including, but not limited to, open container violations, assaults, disturbances, disorderly conduct, or other criminal law violations, or as documented in crime statistics, police reports, emergency medical response data, calls for service, field data, or similar records of a law enforcement agency for the city, town, county, or any other municipal corporation or any state agency.

While a concern for behaviors affecting the general welfare should be a necessary part of the regulation, the inclusion of minor violations like open container violations creates a high risk of arbitrary and burdensome enforcement.

What is more, the statute specifically provides failure to comply with child support as ground for adverse action by the board. The

\footnotetext{
41 Id. § 69.50.331(1).

42 Id.

43 Id.

${ }^{44}$ Id. § 69.50.331(9).

45 Id.
} 
statute specifically mandates that "[t]he state liquor control board shall immediately suspend the license of a person who has been certified . . . by the department of social and health services as a person who is not in compliance with a support order." 46 A child support compliance requirement could negatively impact traditionally disadvantaged groups seeking to maintain gainful employment under this statute. Statistics show a relationship between income, race, and inability to pay fines or financial obligations. ${ }^{47}$ In fact, in the current economic downturn, new reports have surfaced regarding an increased number of individuals being forced to jail due to their inability to pay small debts. ${ }^{48}$

Washington's law could potentially continue this negative trend. The summary punishment of someone in violation of a support order fails to consider the counterproductive nature of this measure: once the license is terminated, it seems that the individual would be even less likely to make the payments. Instead of an immediate termination, a better alternative would be to create a warning structure with notices and set deadlines for remedying the violation. This is all the more reasonable considering that the payment of support is not squarely related to the goals and purposes of the statute's legalization framework. In fact, it arguably runs counter to the statute's expressed purpose of establishing an efficient and equitable implementation of laws related to marijuana.

\section{B. Harsh Penalties for Refusing Breath Tests}

The other problematic feature of the act is the severe punishment levied against an individual who refuses to take a breath test when stopped by law enforcement. The statute provides that,

[a]ny person who operates a motor vehicle within this state is deemed to have given consent ... . to a test or tests of his or her breath or blood for the purpose of determining the alcohol concentration or presence of any drug in his or her breath or blood if arrested for any offense.

\footnotetext{
46 Id. § 69.50.331(2)(b).

47 See generally Lenna Nepomnyaschy \& Irwin Garkinkel, Child Support Enforcement and Fathers' Contributions to Their Nonmarital Children, 84 SOC. SERVICE REV. 341 (2010).

48 See, e.g., Alain Sherter, As Economy Flails, Debtors' Prisons Thrive, CBS NEWS (Apr. 4, 2013, 5:58 PM), http://www.cbsnews.com/8301-505143_162-57577994/as -economy-flails-debtors-prisons-thrive/.

49 WASH. REV. CODE ANN. § 46.20.308(1).
} 
This presumption of consent results in a one-year suspension of one's license when one refuses to submit to a breath test. ${ }^{50}$ It should be noted that harsh consequences for one's refusal to take a breath test are almost commonplace in the United States. Still the movement to reform drug laws should include specific efforts to dismantle inequitable laws and practices, not perpetuate them. The consequences of refusing a breath test become even more dire if it is determined that the person has refused a test before. ${ }^{51}$ Yet, an individual's license is only suspended for ninety days if he or she consents to a test and it is determined that he or she is above the legally sanctioned limit. ${ }^{52}$

The presumption of criminality from the exercise of one's right against self-incrimination creates a catch-22 for anyone stopped by the police. On the one hand, refusal to submit to a breath test carries grave consequences that not only alienate someone's ability to gainfully participate in society (revocation of a driver's license often impacts one's ability to get to work), but often leads to criminal procedures. On the other hand, one who feels targeted and a victim of racial profiling may not always trust that law enforcement will properly administer a breath test. As a result, the swift punishment incorporated in the statute for refusing that test creates a lose-lose scenario that risks perpetuating ongoing patterns of disproportionate and selective enforcement.

\section{Juvenile Conversion of Misdemeanors to Felonies}

In addition to the discretion provided to the state board for consideration of tangential issues like child support in maintaining licenses, the Washington statute's onerous consequences for juveniles should serve as warning for other states. The statute converts the offense of driving under the influence (above the threshold amount allowed by the statute) from a misdemeanor to a Class $\mathrm{C}$ felony "if

50 Id. § 46.20.308(2)(a).

51 Id. § 46.20.3101(1)(a).

52 Id. § 46.20.308(2) ("The officer shall inform the person of his or her right to refuse the breath or blood test, and of his or her right to have additional tests administered by any qualified person of his or her choosing as provided in RCW 46.61.506. The officer shall warn the driver, in substantially the following language, that: (a) If the driver refuses to take the test, the driver's license, permit, or the privilege to drive will be revoked or denied for at least one year; and (b) If the driver refuses to take the test, the diver's refusal to take the test may be used in a criminal trial; and (c) If the driver submits to the test, and the test is administered, the driver's license, permit, or privilege to drive will be suspended, revoked, or denied for at least ninety days.”). 
the person is a juvenile."53 This harsh response to juvenile drug use suggests that, in this new regulatory framework, the school to prison pipeline will be reinforced rather than dismantled. Considering juveniles' high recidivism rate once they are thrust into the penal system, alternative measures, such as drug treatment and focused care along with license suspension, would be more appropriate.

III

\section{CAUTIONARY PRINCIPLES FOR OTHER STATES CONSIDERING LEGALIZATION}

The danger that the current status quo of targeted and selective enforcement will be duplicated remains present as more states consider legalization frameworks similar to Washington's. It should be noted that, while Colorado's statute is not yet as specific as Washington's, it, too, contains a broad mandate that "[l]egitimate, taxpaying business people, and not criminal actors, will conduct sales of marijuana." 54 Residents of Colorado have an opportunity to push their legislators to define terms like "legitimate" and "criminal actors" equitably, to avoid patterns where people with past, unrelated criminal activities might be used as scapegoats and deprived of opportunities under the new regulatory system. After all, as Colorado's statute so elegantly states, the reforms in these two states ostensibly took place "[i]n the interest of the efficient use of law enforcement resources [and] . . . and individual freedom." 55 As a result, the content of the statute needs to be narrowly tailored to achieve these goals. States considering a similar legalization framework to Washington and Colorado should also beware of the potential problems identified in this Article and draft their statutes accordingly.

\section{CONCLUSION}

The new legalization framework for marijuana presents an opportunity to focus on rehabilitation by providing treatment rather than punishment for juveniles and by not prejudicing individuals with

\footnotetext{
53 Id. § 46.61.502(6).

54 Colo. Const. art. XVIII, § 16(1)(b)(IV).

55 Id. § 16(1)(a).
} 
a criminal past. Most jurisdictions, with few exceptions, ${ }^{56}$ have not made rehabilitation a goal. Programs focusing on providing treatment and opportunity demonstrate that a rehabilitation-based model can be more fruitful than the status quo. ${ }^{57}$ Giving a chance to those with a criminal past, once their qualification to run a marijuana processing or retailing business is established, will go a long away to stop the cycle of exclusion they traditionally experience.

It is in our societal interest not to duplicate traditional biases against those with criminal pasts in the burgeoning legalization structures. The number of African Americans and Latinos with a criminal past is so high that a legalization framework that does not focus on rehabilitation will do nothing more than maintain the status quo. This is particularly the case in states with large African American and Latino populations, like New York, Mississippi, and Maryland-where the disproportionate enforcement of drug laws have helped to deplete these communities' capital.

56 Mark A. R. Kleiman \& Kelsey R. Hollander, Reducing Crime by Shrinking the Prison Headcount, 9 OHIO ST. J. CRIM. L. 89, 102-04 (2011) (citing an exception as HOPE: Hawaii's Opportunity Probation with Enforcement).

57 See Honorable Steven S. Alm, A New Continuum for Court Supervision, 91 OR. L. REV. 1181, 1186 (2003) (revealing that after a year in the HOPE program, drug-related probationers were "(1) fifty-five percent less likely to be arrested for a new crime; (2) fifty-three percent less likely to have their probation revoked; (3) seventy-two percent less likely to use drugs; and (4) sixty-one percent less likely to skip appointments with their probation officers”). 